\title{
TTR
}

Traduction, terminologie, rédaction

\section{Diaspora as a Distinct Site of Translational Activity: The Case of U.S. Immigrant Newspapers, 1917-1941}

\section{Brian James Baer et Nike K. Pokorn}

Volume 31, numéro 2, 2e semestre 2018

Minorité, migration et rencontres interculturelles : du binarisme à la complexité

Minority and Migrant Intercultural Encounters: From Binarisms to Complexity

URI : https://id.erudit.org/iderudit/1065572ar

DOI : https://doi.org/10.7202/1065572ar

Aller au sommaire du numéro

Éditeur(s)

Association canadienne de traductologie

ISSN

0835-8443 (imprimé)

1708-2188 (numérique)

Découvrir la revue

Citer cet article

Baer, B. J. \& Pokorn, N. K. (2018). Diaspora as a Distinct Site of Translational Activity: The Case of U.S. Immigrant Newspapers, 1917-1941. TTR, 31(2),

141-165. https://doi.org/10.7202/1065572ar

\section{Résumé de l'article}

Le présent article se veut un plaidoyer en faveur de l'étude de la traduction dans les périodiques publiés aux États-Unis par des communautés immigrantes. Ce contexte interculturel particulier constitue un champ de recherche qui demeure négligé en traductologie. L’article présente des approches méthodologiques qui peuvent être utilisées pour mener ce type d'étude et déterminer l'apport de la traduction dans les communautés diasporiques. Basée sur les approches et méthodes développées en traductologie pour étudier la traduction dans la presse en général, l'analyse porte sur l'(in)visibilité des traductions, la direction des flux de traduction et la nature des textes traduits. Ces aspects mettent en lumière le rôle que joue la traduction dans la construction des identités immigrantes et dans la négociation de la relation entre communauté immigrante et culture dominante, entre communauté immigrante et langue et culture maternelles, et enfin entre générations au sein d'une même communauté immigrante. Les résultats préliminaires qui sont présentés ont pour objet deux périodiques publiés aux États-Unis par des immigrants allophones pendant la période de l'entre-deux-guerres, à savoir le journal slovène Prosveta et le journal russe Novoe Russkoe Slovo. L'analyse révèle la présence constante de la traduction dans ces deux journaux et le fait que celle-ci a été utilisée à des fins différentes, en fonction d'orientations politiques distinctes et de la composition des communautés immigrantes concernées. L'étude montre aussi le rôle de la traduction dans la surveillance exercée par le gouvernement.
Ce document est protégé par la loi sur le droit d'auteur. L'utilisation des services d'Érudit (y compris la reproduction) est assujettie à sa politique d'utilisation que vous pouvez consulter en ligne.

https://apropos.erudit.org/fr/usagers/politique-dutilisation/ 


\title{
Diaspora as a Distinct Site of Translational Activity: The Case of U.S. Immigrant Newspapers, 1917-1941
}

\author{
Brian James Baer \\ Kent State University
}

Nike K. Pokorn ${ }^{1}$

University of Ljubljana

\begin{abstract}
This article argues for the study of translation in U.S. immigrant newspapers, a distinct intercultural context largely ignored in Translation Studies research. The article outlines methodological approaches for the study of translation in immigrant periodicals with the aim of identifying the various roles played by translation in diasporic communities. Based on approaches and methods developed in the field of Translation Studies for researching translation in newspapers, the analysis focuses on the (in)visibility of the translations, the direction of translation flows, and the domain of the translated texts. These categories contribute to our understanding of diaspora as a distinct site of translational activity, through which immigrant identities are constructed and relationships between the immigrant community and the dominant culture, between the immigrant community and its native language and culture, and between different generations within the immigrant community, are negotiated. Preliminary research of two immigrant foreign-language newspapers published in the U.S. in the interwar period, the Slovenian Prosveta, and the Russian Novoe Russkoe Slovo, has documented a consistent presence of translations. The results suggest that translation in these two newspapers was deployed to different ends, reflecting the divergent political orientations of the newspapers and the distinct make-up of these immigrant communities. The study also reveals translation to be a tool of government surveillance.
\end{abstract}

1. Nike K. Pokorn acknowledges the financial support from the Seventh Framework Programme for research, technological development and demonstration, grant agreement 609412 (Project DIFeREns2). 
Keywords: United States, Slovene community, Russian community, Prosveta, Novoe Russkoe Slovo

\section{Résumé}

Le présent article se veut un plaidoyer en faveur de l'étude de la traduction dans les périodiques publiés aux États-Unis par des communautés immigrantes. Ce contexte interculturel particulier constitue un champ de recherche qui demeure négligé en traductologie. L'article présente des approches méthodologiques qui peuvent être utilisées pour mener ce type d'étude et déterminer l'apport de la traduction dans les communautés diasporiques. Basée sur les approches et méthodes développées en traductologie pour étudier la traduction dans la presse en général, l'analyse porte sur l'(in) visibilité des traductions, la direction des flux de traduction et la nature des textes traduits. Ces aspects mettent en lumière le rôle que joue la traduction dans la construction des identités immigrantes et dans la négociation de la relation entre communauté immigrante et culture dominante, entre communauté immigrante et langue et culture maternelles, et enfin entre générations au sein d'une même communauté immigrante. Les résultats préliminaires qui sont présentés ont pour objet deux périodiques publiés aux États-Unis par des immigrants allophones pendant la période de l'entredeux-guerres, à savoir le journal slovène Prosveta et le journal russe Novoe Russkoe Slovo. L'analyse révèle la présence constante de la traduction dans ces deux journaux et le fait que celle-ci a été utilisée à des fins différentes, en fonction d'orientations politiques distinctes et de la composition des communautés immigrantes concernées. Létude montre aussi le rôle de la traduction dans la surveillance exercée par le gouvernement.

Mots-clés : États-Unis, communauté slovène, communauté russe, Prosveta, Novoe Russkoe Slovo

Immigrant communities in general and immigrant newspapers in particular could be said to represent distinct "contact zones," described by Mary Louise Pratt as "social spaces where cultures meet, clash, and grapple with each other, often in contexts of highly asymmetrical relations of power" (1991, p. 34). This was especially true in the U.S. during the inter-war period, which saw an unprecedented upsurge of immigrant newspapers accompanied by increasing government surveillance. By their very nature as representatives of minority communities, immigrant newspapers have a dual orientation, "toward a home that has been lost, and to a place that is not yet home" (Ahmed, 2006, p. 10), helping immigrants integrate into U.S. society while maintaining affective ties to their culture of origin. The relationship of the dominant culture to these foreign-language newspapers has also been complex, even ambivalent. At times these newspapers, and specifically the translations they published, have been treated as sites 
of potential sedition, while at other times they have been seen as useful vehicles for disseminating civic information to non-Englishspeaking citizens and residents. Moreover, as non-governmental entities, these newspapers provide crucial linguistic support when government services are, for political or financial reasons, curtailed. This is especially important given that government-sponsored support for translation and interpreting services is highly sensitive to shifts in the political climate. ${ }^{2}$ Our focus on immigrant newspapers in the U.S. during the inter-war period, therefore, promises to extend and nuance our understanding of diaspora as a distinct site of translational activity, while the comparative dimension of our study highlights the specificity of each immigrant community.

The significance of immigrant newspapers to the U.S. experience has been widely acknowledged by historians (Park, 1922; Klemenčič, 1987, 2008; Petrič, 1993; Kanellos, 2000, 2007; O'Donnell, 2010; Pérez-Rosario, 2013; Avila, 2017), but little scholarly attention has been paid to the role of translations in these venues. And while scholars in the field of Translation Studies have over the last fifteen years studied the role of translation in mass media venues, such as national and international newspapers (Gambier, 2006; Valdeón, 2007, 2012; Bielsa and Bassnett, 2008; Schäffner and Bassnett, 2010; Van Doorslaer, 2010a, 2010b, 2012; Harding, 2011), the specific context of diaspora has been largely ignored. This study, therefore, seeks to bring approaches and methods developed in the field of Translation Studies for researching translation in newspapers to the study of the immigrant experience in a historical context. The methodological approaches to the study of newspapers published by Russian and Slovene immigrant communities in the U.S. outlined below stand to make a significant and timely contribution to scholarship on migrancy, as well as scholarship on translation in mass media outlets.

This study is especially relevant given the increasing availability of these immigrant newspapers in digitized format, as evident in the NEH-funded project Chronicling America, which involves the creation of a digital archive of the major immigrant newspapers in the U.S. All Slovene immigrant newspapers (up to 19483) are also

2. Consider the fact that one of the first moves of the Trump administration was to remove all Spanish translations from the White House web page (The Guardian, 2017; Hohmann, 2017).

3. In order to comply with copyright law. 
publicly available in digitized format provided by the Digital Library of Slovenia (dLib.si). The methodologies devised and tested for this project will provide tools for future scholars who want to make use of these newly created databases to study the role of translation in these newspapers in constructing immigrant identities.

\section{Immigrant Newspapers: Between the National and International}

Two seminal works on the role of print media in our understanding of the modern world reveal a bias toward national and international contexts. On the one hand, Benedict Anderson's Imagined Communities (1991 [1983]) stresses the centrality of "print capitalism" in constructing and supporting a modern national consciousness, first, by promoting a standard "national" language and, second, by representing on its pages what Walter Benjamin described as the "homogenous empty time" of secular modernity (1968, p. 261). According to Anderson, the novel and the newspaper provided "the technical means for 're-presenting' the kind of imagined community that is the nation" (1991 [1983], p. 25). His focus on nations, however, leads Anderson to ignore the often significant presence of translations in those "national" newspapers (see McLaughlin, 2015).

More recently, Susan Buck-Morss in Hegel and Haiti (2009) has argued for a transnational perspective on modern Western philosophy, one that fully incorporates "foreign" texts that circulated both in their original languages and in translation, often in newspapers and journals. Buck-Morss makes a claim for the influence of periodicalscontaining coverage and commentary on current events, such as the Haitian revolution - on Hegel's philosophy, in particular on his conceptualization of the master and slave relationship. Buck-Morss pays special attention to the German journal Minerva, founded in 1804 by Johann Wilhelm von Archenholz, which Hegel read and which "borrowed freely from English and French sources" (BuckMorss, 2009, p. 42). By ignoring these "ephemeral" sources, BuckMorss argues, scholars participate in the "scholarly blindness that silences the past" (ibid., p. 37n). To counter such blindness, BuckMorss's essay is characterized by an

unexpected movement through art catalogues, political journals, foreign translations, internet blogs, workers' newspapers, and college classrooms [...] in response to the unconventional topologies of the time and space mapped out, perhaps more in tune with how we actually live our lives than the histories of separate pasts we have been taught. (ibid., p. ix) 
Indeed, the attention paid to translation by Buck-Morss is unprecedented among historians.

Both national and transnational perspectives on the important role of newspapers in the workings of modern culture, however, tend to ignore or marginalize the specific context of diaspora. This preference for national and international contexts has been largely replicated in the studies of mass media in the field of Translation Studies, despite the growing interest in issues related to translation and migration, which has become "a recurrent trope in recent theoretical writing” (Polezzi, 2012, p. 345). Indeed, Loredana Polezzi argues that the context of migration represents an important lens through which to study the politics of translation, for

while the political nature of language is certainly not exclusive to migration scenarios, migration enhances its visibility, highlighting the interplay of linguistic choices which are variously permitted, frowned upon, singled out for praise, or simply barred. (ibid., p. 346)

In Polezzi's discussion of the "different positions occupied by migrants as agents or objects of translation, and the sites where translation and self-translation take place" (ibid., p. 345), however, there is no mention of newspapers or periodicals, or for that matter, of the immigrant communities that supported them. This is, perhaps, not surprising, given Polezzi's focus on the individual "migrant as artist and self-translator" (ibid., p. 346), whereas translations in newspapers are often anonymous and may represent the compilation of various source-language sources (cf. Bielsa and Bassnett, 2008), thus challenging traditional translation models based on high literature. ${ }^{4}$ It is time, therefore, to pay greater attention to the role of translation in the context of immigrant newspapers as a way to insert some conceptual distance from "a rhetoric of personhood and attendant assumptions of embodied individualism” (Adelson, 2012, p. 358) when we study "what specific forms of translation are mobilized when translation becomes entangled with migration" (ibid., p. 360).

4. It should be noted that this focus on the individual migrant, whether in the guise of the individual artist and self-translator or in that of the individual asylum seeker (Jacquemet, 2009; Davidson, 2000; Inghilleri, 2007) has begun to be redressed in a number of recent studies on "translation policy" or "translational regimes" as a part of a larger discussion of the effects of "language policy" on migration and translation (Meylaerts, 2011; González Núñez, 2016; Pokorn and Čibej, 2017). 


\section{The Hybrid Nature of Immigrant Newspapers}

A site of import and export of ideas, beliefs, and cultural images, translation within diasporic communities is deeply implicated in "identity formation" (Gentzler, 2008) as members negotiate their position as a distinct but still constituent part of the larger culture. ${ }^{5}$ Moreover, the hybridity of translated texts, which "are already referring to at least two different sign systems and cultural traditions" (ibid., p. 2), reflects "one of the most salient aspects of the immigrant experience[-] that of being caught between languages" (Neijmann, 2014, p. 170). ${ }^{6}$ Translated texts, therefore, could be said to represent metonymically if not metaphorically the "hybrid identity formation" (Bassnett, 2008, p. xii) so characteristic of diaspora and migrancy. For this reason, Gentzler argues that translation in the Americas is "less something that happens between separate and distinct cultures and more something that is constitutive of those cultures" (2008, p. 5). While Gentzler goes on to note "the hundreds, even thousands of small papers and magazines [in nineteenth-century America], all publishing in multiple languages, and translating both from the 'foreign' English language into their own and translating their own stories for publication in English journals" (ibid., p. 27), he pays little attention to these immigrant periodicals. This is due no doubt to the labor-intensive nature and the linguistic requirements of such research, a point made in the introduction to a WPA-sponsored study of foreign-language periodicals in the city of Cleveland, known as the Foreign Language Newspaper Digest:

The foreign language press contains part of the priceless record of the process of assimilation. But it is in large part a closed book to the American scholars who are otherwise best prepared to study it, because no one can make a comprehensive study of it, comparing group to group, without an extraordinary command of foreign languages. (WPA, 1937, p. i)

Hence the need for the kind of cross-language collaboration we seek to model with our study.

Situated between their country of origin, or source culture, and their country of destination, or target culture, immigrant newspapers,

5. For more on the role of translation in the construction and circulation of cultural images, see van Doorslaer, Flynn, and Leerssen (2016).

6. For more on the hybridity and multivoicedness of translated texts, see Schäffner and Adab (2001); Hermans (1996), and Schiavi (1996). 
like the translations they choose to publish, negotiate the complex relationship between "foreign" and "domestic" posed by migrancy. Unlike newspapers written in the country's dominant language(s), immigrant newspapers have a dual if not contradictory mission, to preserve an attachment to the immigrants' native language and culture while facilitating immigrants' integration, if not assimilation, into U.S. society. That mission can also be described in terms of the directionality of the newspaper's address: outward, from the immigrant community to the dominant community, and inward, from the dominant community to the immigrant community, as elaborated by Louis Hammerling in the inaugural issue of The American Leader, the official journal of the American Association of Foreign Language Newspapers, which was founded in 1908 and already in 1912 boasted a membership of over 500 newspapers in 29 languages:

The American Leader is to serve two great purposes: to lead the foreign-speaking millions toward still more thorough American citizenship, and to give American people clearer ideas of this great populace of foreign-speaking people which forms now such a great portion of our population. (Hammerling, 1912, p. 7)

This dual orientation or address of immigrant newspapers is reflected in the fact that they often publish translations not only from the dominant language (English) into their community's language but also from their community's language into the dominant language. This makes the question of the direction of translation flows - that is, from what language into what language a translation is done-an especially salient one, as discussed below.

Moreover, these immigrant communities were not homogenous entities but rather consisted of multiple sub-groups, each with its own relationship to the source culture and target culture. This diversity is reflected in the fact that many immigrant communities supported several newspapers, defined by different, often competing, political and regional affiliations, as documented in a 1942 report by the Chicago Library Omnibus Project, funded by the WPA, on foreign-language newspapers in the city of Chicago. For example, the study documented 207 Czech-language newspapers and periodicals published in Chicago since 1855, representing a broad range of political and cultural orientations, ranging from conservative Catholic to radical leftist. The immigrant audience for these newspapers was further divided as members of the younger generation lost proficiency in their parents' native language, leading newspapers to 
include English language texts, either originally authored in English or translated into English, alongside texts written in or translated into the language of the immigrant community. Indeed, the combination of translated and non-translated texts appearing side-byside is a common feature of immigrant newspapers, although not all immigrant newspapers approached translation in this way. Hence the necessity of a typology for the study of translations in the context of immigrant periodicals.

\section{Analyzing Translations in Immigrant Newspapers}

Analysis of the translations will focus on the following: the (in) visibility of the translations, the direction of translation flows, and the domain of the translated texts. The choice of these analytical categories will be described below.

1. Visibility of translations in these newspapers. This category of analysis involves classifying translations as covert, semi-covert, or overt (House, 1981). Covert is used to denote translations that are not marked as such; semi-covert, to denote translations that are not marked as such but that nonetheless reveal themselves to be translations (such as an interview published in a foreign language with a U.S. senator who does not know that language); and overt, to denote those translations that are clearly marked as translations. With the final category, too, some distinctions can be made in terms of how the text is marked as a translation; for example, is the name of the translator or the source language mentioned? Here, we are less concerned with (in)visibility as a reflection of the status of the translator and of translation as elaborated by Venuti (1995) and more in the relationship it implies between the source and target cultures. In other words, the purpose of this analytical category is to assess the (in)visibility of translation in the newspapers and how that (in)visibility participates in the newspaper's negotiation of the immigrant vis-à-vis the dominant national culture. Does the newspaper hide what it borrows or does it purposefully signal that borrowing? What can this tell us about the immigrant community's perception of the dominant culture and its political and cultural authority?

2. Directionality of translation flows in our planned research refers to the relationship between the two languages involved: from 
what (source) language into what (target) language? A great deal of literature has discussed the unequal distribution of cultural capital highlighted by the directionality of translation flows. ${ }^{7}$ Pascale Casanova (2002/2010), for example, proposes an essential difference between translation from a dominated language into a dominating language, which she characterizes as a "consecration" of the foreign work, and translation from a dominating language into a dominated language, which she characterizes as an accumulation of cultural capital. Michael Cronin (1998) has discussed the role translation might play in preserving minor languages. These models, however, were constructed based on distinct national languages and cultures. Our study asks what the directionality of translation flows can tell us about the relationship between source and target language in the specific context of diaspora. Moreover, the comparative dimension of our study allows us to track translation flows across different immigrant newspapers. Prosveta, the Slovene newspaper that is going to be analyzed, for example, published a good number of literary translations into English, alongside translations into Slovenian. The Russian newspaper, Novoe Russkoe Slovo, on the other hand, published very few translations into English. The greater presence of translations in the Slovenian newspapers may be related to the status of Slovenian as a peripheral language (de Swaan, 2001, Heilbron, 1999) in the international literary polysystem.

3. The domain of translated texts (literature, history, science, etc. which can, for example, all be found in Prosveta) highlights the types of knowledge produced by the dominant culture that are most valued by the immigrant community. If we see translation as an "unequal exchange," to use Casanova's term, then what can these commodities tell us about the relationship between source and target cultures? For instance, the translation of advertisements or community announcements in the language of the diasporic community may reveal the perspective of the dominant culture on the immigrant community, while translations of literature or news illustrate the immigrant community's own views on what information is of value.

7. For more on the directionality of translation flows, see Linn (2006) and Kershaw (2014). 
Taken together and analyzed comparatively, these categories allow us to understand the specific role(s) played by translation in negotiating the relationship between the immigrant community and the dominant culture, between the immigrant community and its native language and culture, and between different generations within the immigrant community. Preliminary research has definitively documented the presence of translations in the two foreign-language newspapers selected for analysis, which will be presented in detail below. We are therefore confident that the results of this study will make a significant contribution to our understanding of the complex and shifting role played by foreign-language newspapers in U.S. immigrant communities and of the specific functions of translation in the context of diaspora at precisely a time when these newspapers are becoming more available to researchers in digitized formats.

\section{The Parameters of the Study}

The two immigrant newspapers selected for study were chosen based on their consistent publication history during the period under investigation. The two immigrant communities under investigation in the proposed study, Slovenian and Russian, were selected for their different immigration histories in the interwar period. Slovenians immigrated in large numbers to the U.S. in the late nineteenth century largely for economic reasons, while the mass Russian migration to the U.S. that occurred during and after the Bolshevik Revolution was motivated mostly for political reasons. (Many Slovenes who emigrated after the Second World War did so for political reasons, but this period lies outside the scope of this study.)

The choice of the entre-deux-guerres period was made not simply to set limits on the study in order to guarantee its feasibility, but because this was an especially interesting period in the history of immigrant communities in the U.S. and remains, as Gentzler remarks, "little researched, despite the fact that it is one of the most formative periods in the development of the nation's identity" (2008, p. 27). Following enormous waves of immigration in the late nineteenth and early twentieth centuries, immigrant communities in this period witnessed the coming of age of their first generations of children born in the U.S., with increasingly attenuated ties to their parents' homeland and decreasing proficiency in their parents' native language, which led to the inclusion of English-language texts, including translations, in some immigrant newspapers. 
At the same time, U.S. participation in the First World War fostered suspicion of these immigrant communities in general and of their foreign-language newspapers in particular, as possible sites of sedition, leading to the passage of the Trading with the Enemy Act of October 6, 1917, which required all foreign-language newspapers to obtain prior approval from the Postmaster General before mailing translated material related to the war (Stone, 2004). While the government's war powers were terminated in 1921, the Trading with the Enemies Act was given an extension, and was applied broadly to surveille foreign-language newspapers in immigrant communities deemed potentially hostile to the U.S. throughout the 1920s. For example, Geoffrey Stone cites the case Schaefer v. United States, in which "the [Supreme] Court affirmed [in 1920] the convictions of three men associated with the Philadelphia Tageblatt, a Germanlanguage newspaper, for the offense of translating several articles from English-language newspapers in such a way as to reflect proGerman bias" (2004, p. 210).

In addition, this period saw the passage of the Immigration Act of 1924, also known as the National Origins Act or Johnson-Reed Act, which, based on the 1890 proportions of foreign-born European nationalities and influenced by eugenics, restricted immigration of Southern and Eastern Europeans. This period, which also witnessed a resurgence of the Ku Klux Klan, was marked by a rethinking of the relationship between foreignness and race, leading scholars in the field of Critical Race Theory to designate it as an especially important moment in the construction of the category of "whiteness" in the United States; in fact, it was in 1920 that W.E.B. DuBois wrote: "The discovery of a personal whiteness among the world's peoples is a very modern thing, - a nineteenth and twentieth century matter, indeed. The ancient world would have laughed at such a distinction" (1920, p. 17). ${ }^{8}$

While the federal government became increasingly suspicious, if not hostile, toward immigrant communities during this period, progressives sought to fill the gap. Josephine Roche, for example, transformed the Foreign Language Information Service (FLIS), once a government agency, into a voluntary organization that took a very positive approach to immigrant newspapers, seeing them as a

8. Recent political events in the U.S. have brought new attention to this period, focusing on the resurgence of the Ku Klux Klan and the racism of President Woodrow Wilson (see Yeselson, 2015). 
venue for the dissemination of useful information and for the promotion of civic engagement. Translation was in fact central to the FLIS's work, with the service "routinely translat[ing] press releases from federal agencies and sen[ding] them to 850 newspapers and 67,000 foreign language organizations and their branches" (Muncy, 2015, p. 98). Later, in the 1930s, under the Roosevelt administration, the government took a similarly positive approach to immigrant newspapers and so, too, began to produce and distribute translations for publication in these newspapers.

Others, too, saw these large immigrant communities in a more positive light. For businesses, they represented an untapped consumer market, as evident in the 1922 article "Twelve Millions [sic] Read Papers of Alien Tongues" (August 26,1922), published in The Fourth Estate: A Weekly Newspaper for Advertisers and Newspaper Makers, which encouraged the business community to produce advertising in foreign languages for U.S. immigrant audiences. ${ }^{9}$ Many immigrant newspapers participated in the promotion of "consumer citizenship" not simply by printing these translated advertisements but by actively encouraging their readers to integrate into U.S. society by buying cars and houses (Jenswold, 1992).

This period also saw the publication of the first scholarly study of the immigrant press in the U.S., Robert E. Park's The Immigrant Press and Its Control (1922). Parks argues against strict government control of these newspapers. He mentions in passing a proposal to require an intra-linear translation of all foreign-language newspapers, but argues that this "coercive Americanization" does not work; instead the press should be used "in a cooperative manner" (Parks, 1922, pp. 448449). Later, in the early 1940s, the WPA undertook a comprehensive study of immigrant newspapers in the city of Chicago, known as the Foreign Language Press Survey, hiring writers and sociologists "to translate and classify selected news articles." The authors justify the study in the introduction to their final report:

In the writing of American history, it has been recently recognized that not enough emphasis has been given to the many foreign-born groups who have helped to build this country. Although this neglect has been repaired to some extent in late [sic] years, the study of

9. Hammerling alludes to the consumer power of immigrants when he notes in his preface to the introductory issue of The American Leader: "The American Leader starts with not only the earnest good wishes of a great many public men in high places, but also with the commercial support, in the way of advertising, of the best firms in the country" (1912, p. 7). 
immigrant life in the United States remains largely an untilled field. (Work Projects Administration, 1942)

The study documented the publication of thousands of immigrant newspapers in 23 foreign languages in Chicago alone between 1855 and 1938.

The government's relationship to foreign-language newspapers, however, remained deeply ambivalent as evident in discussions of Japanese-language newspapers following the bombing of Pearl Harbor and the declaration of war with Japan. As Takeya Mizuno writes:

After Pearl Harbor, as the public climate turned sour against the people of Japanese descent, the Roosevelt administration faced a difficult question of how to treat the Japanese "enemy language" newspapers within its borders. While the military-led alarmistexclusionist group of officials demanded to suppress them all, the civilian-led liberal-pragmatic group insisted to preserve and utilize them for national war policies. Their political tug-of-war ended in favor of the latter group, meaning that the Japanese-language press would be immune from total suppression or censorship throughout the war. $(2004$, n. p.)

In this case, the government's ambivalence worked in the favor of the Japanese-American press.

Surveillance, of course, was not limited to official government bodies. Individual citizens, too, might treat readers of immigrant newspapers with suspicion, as the Slovene immigrant writer and translator Louis Adamic noted in My America, an autobiography mixed with social criticism:

Riding in street cars, subways, and elevated trains, old-stock Americans as well as Americans whose background in the United States is a matter of but three or four generations, are wont to feel vaguely uneasy when they see a person next to them reading [...] any of the [...] 1,076 foreign-language newspapers and magazines which are published in the country in thirty-eight different languages. They are wont to give the reader of such a publication a suspicious glance. (1938, p. 238)

As this brief overview of the period suggests, while subjected to increasing government surveillance and general suspicion, these newspapers continued to support the social, cultural and political aspirations of their immigrant readers while seeking to preserve and promote affective ties to their homeland. 


\section{Preliminary Results I: The Slovene Immigrant Newspaper Prosveta}

The Slovenes, one of the smallest European ethnic groups and the western-most Slavic nation in Europe, began emigrating to North America around the turn of the eighteenth century. By the end of the nineteenth century, more than 240,000 Slovenes had immigrated to the U.S., one sixth (16\%) of the entire nation, most of whom were economic immigrants, incentivized by the Homestead Act of 1862 . As explained by the U.S. National Park Service:

The Homestead Act of 1862 was a land law used by the $37^{\text {th }}$ Congress of the United States to distribute the available public lands to private individuals. However, it went beyond the distribution of land and became the United States' first accommodating immigration law; providing all necessary requirements for citizenship. Examining Congressional Debates and the language of the Homestead Act, it is apparent the $37^{\text {th }}$ Congress saw the Homestead Act as a way to build an agricultural nation by encouraging immigrants to settle the public lands of the United States. (National Park Service, 2012, n. p.)

A year after signing the Homestead Act, President Lincoln in his annual speech to Congress called on the government to encourage immigration, after which improvements were made to the Homestead Act and a formal Bureau of Immigration was established.

The first Slovene newspaper in the U.S., Amerikanski Slovenec [The American Slovene], was founded in 1891 in Chicago. By 1927, there were 18 Slovene newspapers of different political orientations and four almanacs in the Slovene language published in the U.S. by the Slovene immigrant community (Jerič, 1927). Still in publication today, Prosveta [Enlightenment] is a politically progressive Slovenelanguage daily that began publication in 1916 in Chicago. During the period under investigation, the newspaper consisted of four to eight pages; the first two pages were dedicated to international and domestic U.S. news, while the remaining pages were dedicated to news from Slovene-American locales around the U.S., and from Slovenia. Funded by Slovenska Narodna Podporna Jednota [Slovene National Benefit Society], Prosveta also functioned as a private newsletter (see Pogačar, 2017). Typically, the last two pages were dedicated to culture and advertisements, which included the publication of original Slovene literary works as well as translations of foreign literary works into Slovene. An overview of more than 6,300 issues of Prosveta shows that translations were included in 
every issue: each issue contained not only translations of news and advertisements, but also translations of literary works from various languages into English (see Figure 1).
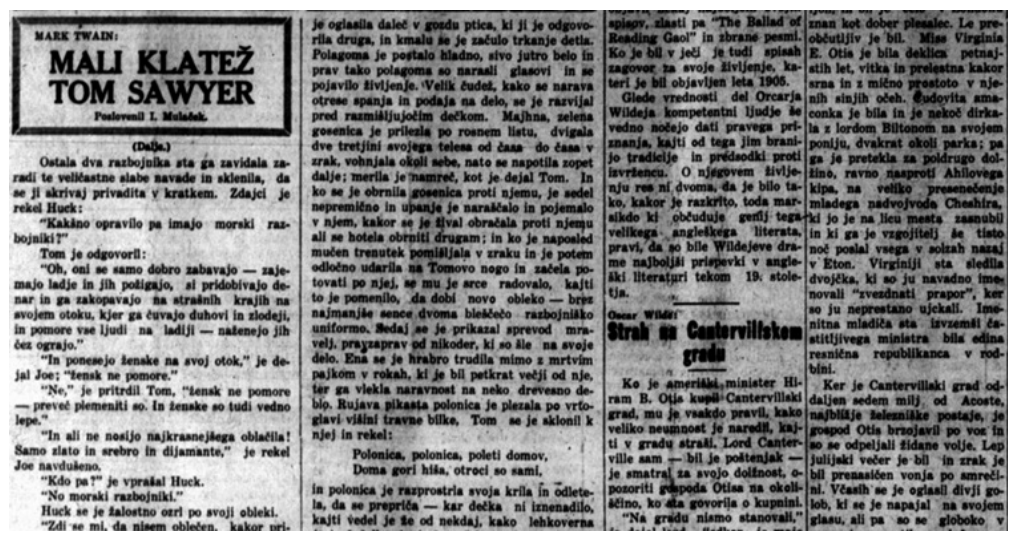

Figure 1. Installments of a Slovene translation of Mark Twain's

Tom Sawyer and of Oscar Wilde's novella The Canterville Ghost, the latter prefaced by a short overview of the author's oeuvre (Prosveta, 4/23/1927, p. 4)

The introduction of the Immigration Act of 1924 led to a sharp decrease in the number of Slovene immigrants. ${ }^{10}$ The aging of native speakers of Slovene in the U.S. immigrant community resulted in a language shift from Slovene to English. This was reflected in their periodicals by the introduction of the so-called English sections, i.e., pages in English for the members of their community who were more proficient in English than in Slovene. These sections soon included translations of Slovene literary works into English, partly to reach the new generations of the community who had lost their native language, and partly to present Slovene cultural achievements to mainstream U.S. culture. In this respect, the diaspora served as cultural ambassador for Slovene literature and culture in general, largely unknown to the English-reading public, insofar as these were the first translations of Slovene literary works into English (Pokorn, 2005) (see Figure 2, next page).

10. After the collapse of Austria-Hungary following the First World War, Slovenes became citizens of the Kingdom of Serbs, Croats and Slovenes and later of the Kingdom of Yugoslavia, and were therefore considered to belong to Southern Europe. 


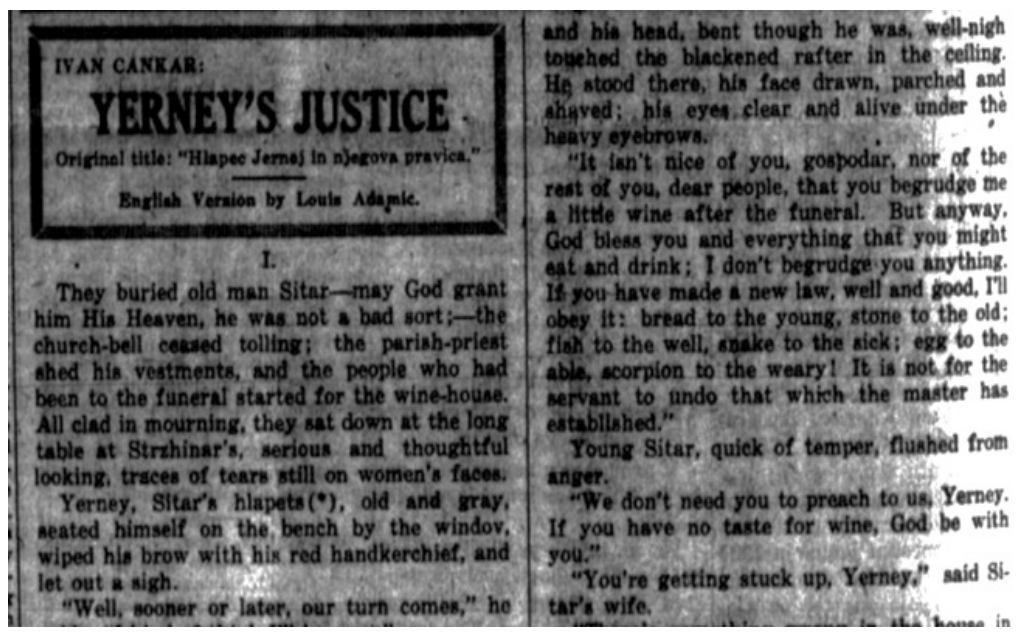

Figure 2. Publication of the first translation of Slovene literature into English (Prosveta, 5/19/1926, p. 6)

The language shift in newspapers mirrored the language shift in immigrant organizations. For example, Prosveta was published by Slovenska Narodna Podporna Jednota (S.N.J.P.), the largest Slovene immigrant organization in the U.S. The introduction of English pages was explained by the newspaper in the following way:

There are many young men and women in our Jednota; but I have noticed that very few of them attend our monthly meetings, because they think to themselves, "Well, I guess, I won't go to the meeting; about all they do is talk politics, and everything is said in Slovenian, which I don't understand so well; so all I do is pay my dues and go to a dance." $[\ldots]$ The primary object of organizing American-speaking subordinate lodges of the S.N.P.J. is to make the American-speaking members of the S.N.P.J. who are now members of some Slovenianspeaking lodge, interested in lodge work, thereby making them active members. The method through which this is accomplished is by holding all business and social meetings in the American [sic] language, in a language they can understand, comprehend, and express their own views and ideas. (Prosveta, 1/6/26, p. 6)

The Slovene community's relationship to translation and to the use of English is clearly related to its history of immigration, which was sharply curtailed in the early part of the twentieth century. Without an influx of new immigrants, the process of linguistic assimilation inevitably played itself out on the pages of its newspapers. 


\section{Preliminary Results II: The Russian Immigrant Newspaper Novoe Russkoe Slovo}

The first major wave of Russian immigrants to North America was related to the Russian colonization of what is today Alaska and Northern California in the late eighteenth and early nineteenth centuries. The second, much larger, wave of immigration occurred at the end of the nineteenth century and the beginning of the twentieth. While some Russian citizens emigrated for economic reasons, most were led to emigrate by the anti-Jewish pogroms that swept across the southern territories of the Russian empire in the early 1880s. That wave ended with the emigration of political refugees following the Bolshevik Revolution in 1917 (see Magocsi, 1988). The fact that the homeland of these immigrants was now socialist-whereas Slovene immigrants' homeland in this period was not-may help to explain the far more visible censorship exerted on Russian immigrant newspapers, which will be described below. The fact that the Russian diaspora was constantly refreshed by new waves of immigrants may also help to explain why translations into English played almost no part in Russian immigrant newspapers, again, unlike in their Slovene counterparts. One of the rare cases in which English was used was to provide a sample letter to send to the Governor of Michigan asking him to pardon the imprisoned Russian worker Peter Matzkewich (Novoe Russkoe Slovo 10/26/1920, p. 2).

One of the largest and longest-running Russian immigrant newspapers was founded in New York City in 1910 as Russkoe Slovo, or The Russian Word. The title of the newspaper was changed in August of 1920 to Novoe Russkoe Slovo, or The New Russian Word. The name change, which occurred during the so-called "Red Panic" following the October Revolution, was probably meant to distance the paper from its leftist past, although the fact that the newspaper retained its original editor, I. K. Okuntsov, suggests that the name change was largely cosmetic. In 1921, the newspaper had a circulation of 32,400 , and by the 1930s it had become the largest Russian-language newspaper in the U.S.

Before 1921, the newspaper's use of translation was for the most part covert. The presence of translations was implied when the source of an article was clearly non-Russian, such as the Federated Press, which was a left-wing English-language news service founded in 1920. Those articles, therefore, were clearly translations, although they were not overtly marked as such, nor was the name of the translator 
provided. (Their status as a translation was also suggested, however, by the non-Russian names of the authors, such as Paul Hanna, a regular contributor to the Federated Press.) Other covert translations included interviews with English-speaking cultural figures and politicians, such as U.S. Senator Joseph France (1/20/1921, p. 1), the Indian revolutionary and Columbia professor Tarak Nath Dass (1/29/1921, p. 3), and the British sculptor Clare Sheridan (2/2/1921, p. 3). Names of translators were typically provided only with literary works, although not always even then. Moreover, there appears to have been no generally accepted norms for indicating a translation. For example, a short story "Pipita" (10/30/1920, p. 3) indicates at the top, next to the title, that this is "(An authorized translation)" of a story by M. I. Khaimovich, but without the name of the translator, while a translated sonnet $(1 / 22 / 1921$, p. 2$)$ is accompanied by a note at the bottom: "(From the English of J. B. Guimes)," with the author's name in Latin letters and the translator's name, Mariia Lir, bolded and in Cyrillic, and not in parentheses, alongside it.

In 1921, however, translation was highlighted as both a potential site of sedition and as a means of surveillance when the government censored Novoe Russkoe Slovo under the Trading with the Enemy Act of October 16, 1917. This was announced on the front page of the paper with the headline: "Novoe Russkoe Slovo vziato pod tsenzuru" [New Russian Word under censorship]:

\section{„Новөе Русское Слово” взято под цензуру}

Почтовый департамент из Вашингтона сообщил издателю ,Новаго Русск. Слова", что он отбирает у него привилигію на печатаніе газеты без представленія переводов на англійскій яз.

Это ограниченіе, в сво время распространенное на всь радикальныя газеты, вступает для „Новаго Русскаго Слова” в силу, начиная со сегодняшняго дня.

Figure 3. Announcement of government censorship (Novoe Russkoe Slovo, 2/11/1921, p. 1) 
The short announcement read:

The Postal Department in Washington has informed the publisher of New Russian Word that it was depriving him of the privilege of publishing the newspaper without presenting translations into the English language. This limitation, which in its time had applied to all radical newspapers, now enters into effect for New Russian Word beginning today. (2/11/1921, p. 1 ; translated by B. Baer)

The wording here suggests that Novoe Russkoe Slovo did not see itself as a "radical" newspaper, but that the law had now been extended to include it. Moreoever, the Trading with the Enemy Act, referred to metonymically with the date of its passage, was designed not only to restrict trade with countries hostile to the United States, but also to prohibit:

to print, publish, or circulate, or cause to be printed, published, or circulated in any foreign language, any news item, editorial or other printed matter, respecting the Government of the United States, or of any nation engaged in the present war, its policies, international relations, the state or conduct of the war, or any matter relating thereto. (HR 4960, Sec. 19)

The act goes on to elaborate translation as one of the conditions under which publication and circulation of such texts would be possible:

with the postmaster at the place of publication, in the form of an affidavit, a true and complete translation of the entire article containing such matter proposed to be published in such print, newspaper, or publication, and has caused to be printed, in plain type in the English language, at the head of each such item, editorial, or other matter, on each copy of such print, newspaper, or publication, the words "True translation filed with the postmaster at on (naming the post office where the translation was filed, and the date of filing thereof), as required by the Act of (here giving the date of this Act)." (HR 4960, Sec. 19)

It is interesting that in many of these statements published in Novoe Russkoe Slovo, "true" is misspelled as "trye" (see Figure 4, next page), a possible act of defiance or perhaps a Freudian slip as the law put the newspaper under threat of being "tried" in court.

A law that had been originally designed to control the circulation of reporting and commentary on the war was extended very broadly in the 1920s to apply to any potentially "hostile" content published in a foreign language. Whereas with Schaefer v. United 
States, mentioned above, the law was applied to police translations of English into a foreign language, in the case of Novoe Russkoe Slovo, the law was applied to keep track of material borrowed from Soviet and pro-Soviet news outlets, and was clearly designed to discourage the circulation of "radical" commentary. The application of the law revealed that between five and ten articles per issue were taken from foreign sources.

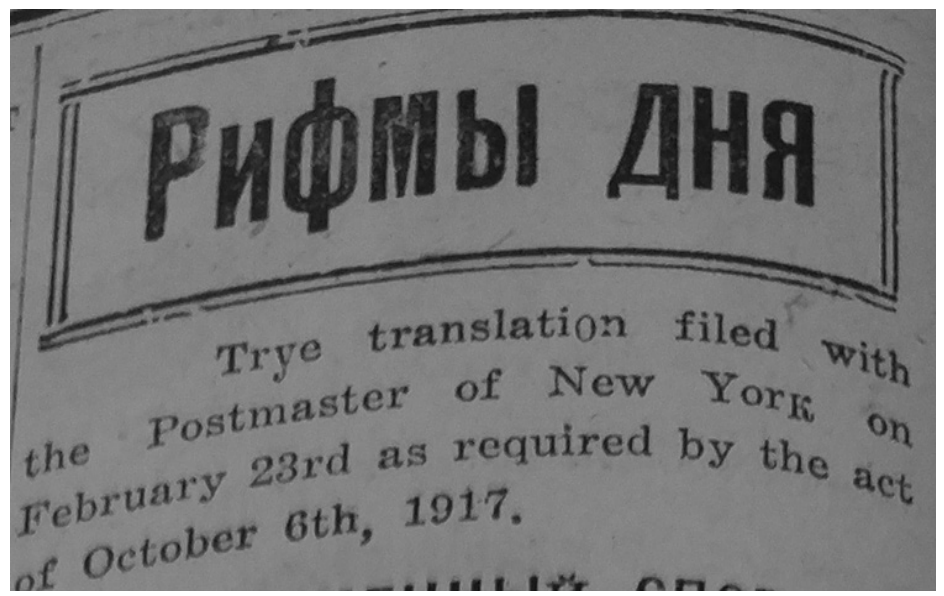

Figure 4. Example of misspelling of "true" (Novoe Russkoe Slovo, 2/24/1921)

\section{Conclusion}

This preliminary study of translations in two immigrant newspapers published in the USA in the interwar period, i.e., the period of the greatest expansion of the US immigrant press, sheds new light on diaspora as a distinct site of translational activity. Through translations, immigrants sought to negotiate a relationship with their new home while retaining a relationship to their homeland of origin. At the same time, immigrant communities were treated with ambivalence by the dominant Anglophone culture, which saw them alternately as potential consumers and citizens and as potential traitors. The former viewpoint promoted the translation of important information to promote assimiliation and civic engagement while the latter led to the surveillance and censorship of translated materials. Moreover, the comparative nature of this study revealed key differences in the use of translation in the two diasporic communities under investigation. 
For example, due to the sharp decline in the arrival of new Slovene immigrants after the introduction of the Immigration Act of 1924, translations of Slovene literary texts into English began to appear alongside translations of literary texts into Slovene in the newspaper Prosveta, in order to meet the shifting needs of the Slovene diaspora. The Russian immigrant community, by contrast, was continually refreshed by new waves of Russian-speaking immigrants, and so translations out of Russian into English remained rare in Novoe Russkoe Slovo.

Such small-scale studies can and should be expanded both diachronically, to include other historical periods, and synchronically, to include more immigrant communities, each with its own history and diasporic identity. The study of Spanish-language newspapers in the period, for example, could provide additional insights into the role of translation in the immigrant press, as Spanish-speaking communities in the U.S. were, in many cases, mixed, in the sense that they were composed of recent immigrants and non-immigrants, that is, those whose families had settled in the region before it became incorporated into the U.S. Those communities then saw an upsurge in economic immigration from Mexico between 1910 and 1924, with half a million Mexicans settling in the U.S. (Kanellos, 2000, p. 34). Such extensions could contribute to our understanding of the commonalities as well as the differences among the various immigrant newspapers, while also highlighting the various and shifting roles played by translation in navigating the immigrant experience. Moreover, translation in immigrant newspapers could be studied alongside other diasporic translational activity, such as selftranslations by immigrant writers and book translations supported by immigrant publishing houses to provide a broader picture of diaspora as a distinct translation zone.

\section{References}

Adamic, Louis (1938). My America. New York, Harper.

Adelson, Leslie A. (2012). "Response to the article 'Translation and Migration,' by Loredana Polezzi, published in Translation Studies, 5, 3, pp. 345-356." Translation Studies, 5, 3, pp. 356-361.

Ahmed, Sara (2006). Queer Phenomenology. Orientations, Objects, Others. Durham and London, Duke University Press.

Anderson, Benedict (1991 [1983]). Imagined Communities: Reflections on the Origins and Spread of Nationalism. London, Verso.

Avila, Alexander James (2017). Ethnic Newspapers and Journalistic Advocacy 
in the 21st Century: A Content Analysis Using Immigration Frames. Unpublished dissertation. University of Texas at Austin.

Bassnett, Susan. (2008). "Foreword." In E. Gentzler, ed. Translation and Identity in the Americas: New Directions in Translation Theory. London, Routledge, pp. ix-xiv.

Benjamin, Walter. (1968). "Theses on the Philosophy of History." In Illuminations. New York, Schocken Books, pp. 253-264.

Bielsa, Esperança and Susan Bassnett (2008). Translation in Global Nerws. New York, Routledge.

Buck-Morss, Susan (2009). Hegel, Haiti, and Universal History. Pittsburgh, University of Pittsburgh Press.

Casanova, Pascale (2002/2010). "Consecration and Accumulation of Literary Capital: Translation as Unequal Exchange.” In M. Baker, ed. Critical Readings in Translation Studies. New York, Routledge, pp. 285303.

Cronin, Michael (1998). "The Cracked Looking Glass of Servants: Translation and Minority Languages in a Global Age." The Translator, 4, 2, pp. 145-162.

Davidson, Brad (2000). “The Interpreter as Institutional Gatekeeper: The Social邓linguistic Role of Interpreters in Spanish区English Medical Discourse." Journal of Sociolinguistics, 4, 3, pp. 379-405.

De Swaan, Abram (2001). Words of the World. Cambridge, Polity.

DuBois, W. E. B. (1920). Darkwater: Voices from within the Veil. New York, Harcourt Brace and Company.

Gambier, Yves (2006). "Transformations in International News." In K. Conway and S. Bassnett, eds. Translation in Global Nerws. Coventry, University of Warwick, pp. 9-21.

Gentzler, Edwin (2008). Translation and Identity in the Americas: New Directions in Translation Theory. London, Routledge.

Gentzler, Edwin (2011). "Macro- and Micro-turns in Translation Studies." In L. van Doorslaer and P. Flynn, eds. Eurocentrism in Translation Studies, special issue of Translation and Interpreting Studies, 6, 2, pp. 121-141.

Gonzáles Núñez, Gabriel (2016). Translating in Linguistically Diverse Societies: Translation Policy in the United Kingdom. Amsterdam/ Philadelphia, John Benjamins.

Hammerling, Louis N. (1912). "Preface." The American Leader, 1, 1, p. 7.

Harding, Susan (2011). "Making a Difference? Independent Online Media Translations of the 2004 Beslan Hostage Disaster." The Translator, 18, 2, pp. 339-361.

Heilbron, Johan (1999). "Towards a Sociology of Translation: Book Translation as a Cultural World-System." Acoustics, Speech, and Signal Processing Newsletter, IEEE, 2, 4, pp. 429-444.

Hermans, Theo (1996). "The Translator's Voice in Translated Narrative." 
Target, 8, 1, pp. 23-48.

Hohmann, James (2017). "The Daily 202: The Liberal Tea Party Movement Has Begun. What Will Become of It?” The Washington Post, 23 January. Available at <https://www.washingtonpost.com/ news/powerpost/paloma/daily-202/2017/01/23/daily-202-theliberal-tea-party-movement-has-begun-what-will-become-ofit/58854577e9b69b432bc7e066/?utm_term $=.61780 \mathrm{e} 33 \mathrm{f7c} 9>$ [accessed 3 March 2018].

House, Juliane (1981). A Model for Translation Quality Assessment. $2^{\text {nd }}$ Edition. Tübingen, Gunter Narr.

Inghilleri, Moira (2007). "National Sovereignty versus Universal Rights: Interpreting Justice in a Global Context." Social Semiotics, 17, 2, pp. 195-212.

Jacquement, Marco (2009). "Transcribing Refugees: The Entextualization of Asylum Seekers' Hearings in a Transidiomatic Environment. " Text E Talk, 29, 5, pp. 525-546.

Jenswold, John R. (1992). "Becoming American, Becoming Suburban: Norwegians in the 1920s." Norwegian-American Studies, 33, pp. 3-26.

Jerič, John (1927). “Slovensko časopisje v Ameriki." In Koledar Ave Maria. Chicago, Edinost, pp. 117-119.

Kanellos, Nicolás (2000). Hispanic Periodicals in the United States: Origins to 1960. Houston, Arte Público Press.

Kanellos, Nicolás (2007). "Recovering and Re-constructing Early Twentieth-century Hispanic Immigrant Print Culture in the US." American Literary History, 19, 2, pp. 438-455.

Kershaw, Angela (2014). "Complexity and Unpredictability in Cultural Flows: Two French Holocaust Novels in English Translation." Translation Studies, 7, 1, pp. 34-49.

Klemenčič, Matjaž (1987). "Mass Media among the Slovene Immigrants." In I. Štrukelj, ed. Minority Languages and Mass Communication. Ljubljana, Slovene Association of Applied Linguistics, pp. 177-180.

Klemenčič, Matjaž (2008). "Slovene Periodicals in the USA, 1891-1920." Treatises and Documents: Journal of Ethnic Studies, 55, pp. 98-117.

Linn, Stella (2006). "Trends in Translation of a Minority Language: The Case of Dutch." In A. Pym, M. Schlesinger and Z. Jettmarova, eds. Sociocultural Aspects of Translating and Interpreting. Amsterdam/ Philadelphia, John Benjamins, pp. 27-40.

McLaughlin, Mairi Louisa (2015). "News Translation Past and Present: Silent Witness and Invisible Intruder.” Perspectives, 23, 4, pp. 552-569.

Meylaerts, Reine (2011). "Translational Justice in a Multilingual World: An Overview of Translational Regimes.” Meta, 56, 4, pp. 743-757.

Mizuno, Takeya (2004). “To Suppress or not to Suppress, That is the Question: Pros and Cons over the Suppression of the Japanese-language Press from Pearl Harbor to Mass Evacuation." Paper presented at the 
Association for Education in Journalism and Mass Communication. Toronto, Canada.

Muncy, Robyn (2015). Relentless Reformer: Josephine Roche and Progressivism in Twentieth-century America. Princeton and Oxford, Princeton University Press.

National Park Service. 2012. "The Impact of the Homestead Act on Immigration." Available at <https://home.nps.gov/resources/2016. $\mathrm{htm} ? \mathrm{id}=54351 \mathrm{ACE}-155 \mathrm{D}-4519-3 \mathrm{E} 0 \mathrm{~B} 009016 \mathrm{~F} 83 \mathrm{CFB}>$ [accessed 31 March 2019].

Neijmann, Daisy (2014). “Foreign Immigrants Write back: The Publication of Laura Goodman Salveson's The Viking Heart." In K. Mezei, S. Simon and L. von Flotow, eds. Translation Effects: The Shaping of Modern Canadian Culture. Montreal, McGill-Queen's University Press, pp. 163-173.

O'Donnell, Mary (2010). Assimilation, Rejection or Convergence? The Role of the Bilingual Press in San Antonio, Texas. Unpublished Ph.D. Dissertation. Southern Illinois University Carbondale.

Park, Robert E. (1922). The Immigrant Press and Its Control. New York, Harper and Brothers.

Pérez-Rosario, Vanessa (2013). "Julia De Burgos' Writing for Pueblos Hispanos: Journalism as Puerto Rican Cultural and Political Transnational Practice." Centro Journal, 25, 2, pp. 4-27.

Petrič, Jerneja (1993). "The Slovene-American Press as a Medium for Growing Literary Activities: From the Times of Early Immigration until the 1930's." Slovenski koledar: koledar za Slovence po svetu, 40, pp. 203-208.

Pogačar, Timothy (2017). "Izseljenski tisk v Ameriki v digitalni dobi: slovensko-ameriški časopis Prosveta”. Slavistična revija: časopis za jezikoslovje in literarne vede = Journal for linguistics and literary studies, 65, 2, pp. 343-353.

Pokorn, Nike K. (2005). Challenging the Traditional Axioms: Translating into a Non-mother Tongue. Amsterdam/Philadelphia, John Benjamins.

Pokorn, Nike K. and Jaka Čibej (2017). "Interpreting and Linguistic Inclusion-Friends or Foes? Results from a Field Study." The Translator, 24, 2, pp. 111-127.

Polezzi, Loredana (2012). "Translaton and Migration.” Translation Studies, 5, 3, pp. 345-356.

Pratt, Mary Louise (1991). "Arts of the Contact Zone." Profession. New York, MLA, pp. 33-40.

Schäffner, Christina and Beverly Adab (2001). "The Idea of the Hybrid Text and Translation: Contact as Conflict." Across Languages and Cultures, 2, 9, pp. 167-180.

Schäffner, Christina and Susan Bassnett (2010). Political Discourse, Media and Translation. Newcastle upon Tyne, Cambridge Scholars Publishing.

Schiavi, Giuliana (1996). “There is Always a Teller in a Tale.” Target, 8, 1, pp. 1-21. 
Stone, Geoffrey R. (2004). Perilous Times: Free Speech in Wartime from the Sedition Act of 1798 to the War on Terrorism. New York, Norton.

The Guardian (2017). "Spain Concerned over Missing White House Spanish Website: 'Not a Good Idea'" The Guardian, January 23. Available at <https://www.theguardian.com/world/2017/jan/23/spainspanish-white-house-website> [accessed 3 March 2018].

Valdeón, Roberto (2007). "Ideological Independence or Negative Mediation: BBC Mundo and CNN en Español's (translated) Reporting of Madrid's Terrorist Attacks.” In M. Salama-Carr, ed. Translating and Interpreting Conflict. Amsterdam and New York, Rodopi, pp. 99-118.

Valdeón, Roberto (2012). "From the Dutch Corantos to Convergence Journalism: The Role of Translation in News Production.” Meta, 57, 4, pp. 850-865.

Van Doorslaer, Luc (2010a). “Journalism and Translation.” In Y. Gambier and L. van Doorslaer, eds. Handbook of Translation Studies, Volume 1. Amsterdam/Philadelphia, John Benjamins, pp. 180-184.

Van Doorslaer, Luc (2010b). "The Double Extension of Translation in the Journalistic Field." Across Languages and Cultures, 11, 2, pp. 175-188.

Van Doorslaer, Luc (2012). "Translating, Narrating and Constructing Images in Journalism with a Test Case on Representation in Flemish TV News.” Meta, 57, 4, pp. 1046-1059.

Van Doorslaer, Luc, Peter Flynn and Joep Leerssen, eds. (2016). Interconnecting Translation Studies and Imagology. Amsterdam/Philadelphia, John Benjamins.

Venuti, Lawrence (1995). The Translator's Invisibility. New York, Routledge. Work Projects Administration (WPA) (1942). Chicago Public Library Omnibus Project. Washington, D.C., Work Projects Administration.

Yeselson, Richard (2015). "The Return of the 1920s." The Atlantic. December 30. Available at <https://www.theatlantic.com/politics/archive/2015/12/ the-return-of-the-1920s/422163/> [accessed 2 March 2018].

Brian James Baer Department of Modern \& Classical Language Studies Kent State University Kent, Ohio, United States bbaer@kent.edu

Nike K. Pokorn Department of Translation Studies University of Ljubljana Ljubljana, Slovenia <nike.pokorn@ff.uni-lj.si 